\title{
Exposure Sequence Number
}

National Cancer Institute

\section{Source}

National Cancer Institute. Exposure Sequence Number. NCI Thesaurus. Code C83286.

An identifier that describes the relative position of an exposure data within a series. 